九病虫研会報 $40 ： 137-142$ (1994)

Proc. Assoc. Pl. Prot. Kyushu 40：137-142（1994）

\title{
長崎県に打けるツツジグンバイの発生予察法
}

第 2 報：ツツジグンバイの卵と各齢幼虫の発育零点と有効

温度および積算温度法則を用いた本種の発生予察

中須賀孝正（長崎県総合農林試験場）

\section{Forecasting methods for the occurrence of the azalea lace bug, Stephanitis pyrioides in Nagasaki prefecture.}

2. Developemental zero and total effective temperatures for eggs and each nymphal stage of the azalea lace bug, Stephanitis pyrioides and the use of temperature-sum rule for assessing seasonal prevalence of the field population. Takaakira NAKASUGA (Nagasaki Agriculural and Forestry Experiment Station, Isahaya, Nagasaki 854)

Overwintered eggs of the azalea lace bug, Stephanitis pyrioides (Heteroptera: Tingidae) were collected in February and March in Nagasaki and the hatching trend of the eggs and developmental rate of the nymphs emerged were examined under 3 or 4 constant temperatures. Development of overwintered eggs was linear arcoss temperatures and developmental zero and total effective temperature were estimated to be $10^{\circ} \mathrm{C}$ and 150 day-degrees, respectively. Development of nymphal instars across temperatures was linear as well. Developmental zero of 1 st, 2 nd, 3rd, 4th and 5 th instar nymphs were estimated to be $9.5^{\circ} \mathrm{C}, 9.5^{\circ} \mathrm{C}, 9.9^{\circ} \mathrm{C}, 8.8^{\circ} \mathrm{C}$ and $10.3^{\circ} \mathrm{C}$, respectively. Total effective temperatures of $1 \mathrm{st}, 2 \mathrm{nd}, 3 \mathrm{rd}$, 4 th and 5 th nymphal instars were estimated to be $48.7,37.5,36.0,52.2$, and 57.6 day degrees, respectively. The total effective temperature of the whole nymphal instar was estimated to be 217.9 day $\cdot \mathrm{degr}-$ ees.

In Nagasaki, this insect overwintered in the egg stage and 1st instar nymph appeared in the middle of April. The adult stage of overwintered generation appeared in late May and after that 3 generations were observed within a year. A trial for forecasting seasonal occurence of the insect using the thermal constants explained above was conducted in Isahaya city, Nagasaki.

近年の花き類生産の增加にともない病害虫の発生も增 加変容してきた。なかでもッッジは室内鑑賞用, 庭木, 街路樹用として生産の増加が著しい花きの一つであるが, これに寄生するッッジグンバイはッッジの美観を著しく 損なうため，本種の的確な発生予察にもとづく防除法の 確立が必要となっている。

本種の形態や生態に関しては TAKEYA (1963), NEAL and DouGLASS (1988) 等の報告があるが, 有効積算温 度法則に基づく発生予察に必要な各態の有效温量につい ての知見は十分でない。

そこで本種の各態の発育最低温度と有効温量を調べ, また,これにもとづいて1992年および1993年の発生時期 を予浿し実際との適合性を検討した。

\section{材料と方 法}

\section{1. 越冬卵の心化時期}

供試材料としてのッッジは長崎県諫早市貝津町の県総 合農林試験場構内植栽のヒラドッッジ (30年生：調查地 点諫早1-1）および農試近隣宅地の街路樹として植栽さ れているヒラドッッシ (15年生：諫早 2$)$ ，抢よび諫早 市内の公園内（諫早 3 ）と南高来郡口之津町内（口之 津）にそれぞれ街路樹として植栽されているヒラドッッ ジの計 4 ヶ所のッッジを用いた。

供試ツッジの技の採取は1993年 2 月20日〜25日および 3 月 8 日に行った。各採取地点のッッジ数株を任意にえ らび，その先端技を各々20枝程度採取し，各枝の莱を調 
ベてッッジグンバイの加害痕跡があり即の産下が想定さ れた葉合計60葉を選んで試験に供した。

供試葉は吸水させたろ紙を敷いた直径 $8 \mathrm{~cm}$ のプラスチ ックシャーレに 3 枚づつ接触しないように収納し，15， $20 ， 25^{\circ} \mathrm{C}$ の 3 温度段階の長日条件下（16L: $8 \mathrm{D}$ ；以下長 日条件は $16 \mathrm{~L}: 8 \mathrm{D}$ とする）に保持した。 3 月 8 日採取 分は $25^{\circ} \mathrm{C}$ 全暗下に保持した。

ふ化時期とふ化の有無の調查は所定温度下に収納 1 日 後から原則として每日午前 9 時頃と午後 8 時頃の 2 回行 なった。

\section{2. ッッジグンバイ幼虫各態の発育最低温度と有効温 量}

供試材料としてのッッジは諌早市の県総合農林試験場 構内のヒラドッッジ（30年生；諫早1-2）とした。1993 年 2 月 1 日に任意に選定した株の先端枝約20枝を採取し， このうち卵の産下が想定された60葉を供試した。

採取葉は $25^{\circ} \mathrm{C}$ 恒温の長日条件下に保持し, 毎日午前 9 時頃と午後 8 時頃の 2 回ふ化状況の調查を継続し，12時 間以内にふ化した幼虫を試験に供した。ふ化幼虫は吸水

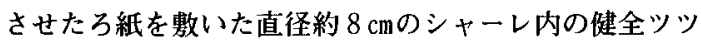
ジ葉に移して収納し，15，20，25，28 ${ }^{\circ} \mathrm{C} の 4$ 温度段階の 長日条件下で飼育し，脱皮を確認しながら加齢過程を調 查した。

\section{3. 発生状況}

\section{1) 調查地点}

長崎県諫早市貝津町の長崎県総合農林試験場内の県観 察戋のヒラドッッジ（品種：大紫 3 年生; 諫早 $1-1$ ), および同試験場構内のヒラドッッシ (30年生; 諫早 1 2）および諫早市内宅地の街路樹として植栽されている ヒラドッッジ（15年生; 諫早 2）の3地点とした。

\section{2) 調查方法}

越冬状況調查は成虫については 3 月中旬に見取りおよ び粘着板またはバット上払い落し法で行った。即越冬に ついては 2 月 1 日〜 3 月下旬に採取した前年生20枝の $25^{\circ} \mathrm{C}$ ，長日下での幼虫のふ化調査によって行った。

年間発生消長の謂查は 4 月から11月までほぼ 7 10日 間隔で各月に $3 \sim 4$ 回行った。調査株数は原則として, 発生が比較的少なかった諫早 $1-1$ では25株, 発生が多 かった諫早 $1-2$ と諫早 2 では 5 株とし, 調查枝数は株 当り 5 枝とした。なおッッジグンバイの密度が高くなつ た時期 (7 月以降) には諫早 $1-1$ では調查株数を10株 程度に, 最小では 6 株に減らした。所定調查時期に各枝 の寄生成虫数，秢期別幼虫数を，虫態の大きさに応じて 適宜，肉眼または 5 10倍のルーペ下で調查した。幼虫 齢期の判別は中須賀 (1993) の判別法によった。

\section{䊅果および考察}

\section{1. 越冬卵のふ化と温度との関係}

3 温度段階における越冬卵の飼育結果を Table 1 に 示した。2月20日〜25日に採取した卵は，長日条件下で

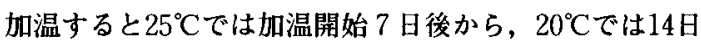
後からふ化した。また $15^{\circ}$ C以下では25日からふ化した。

3 月 8 日に採取した $25^{\circ} \mathrm{C}$ 全暗下飼育でも 2 月下旬に採 取した長日下の加温区と同様に，加温開始 6 日後からふ 化した。調查したいずれの地点の越冬卵とも，そのふ化 はかなり整一でありふ化曲線は正規分布曲線に類似した。

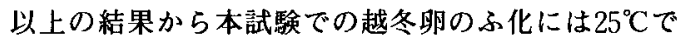

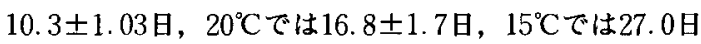

Table 1. Hatching trend of overwintered eggs of Stephanitis pyrioides collected in late February and in early March at 3 sites in Isahaya city and Kuchinotsu, Nagasaki and incubated at three constant temperatures ${ }^{a)}$.

\begin{tabular}{|c|c|c|c|c|c|c|}
\hline \multirow{3}{*}{$\begin{array}{l}\text { Days, after } \\
\text { incubation }\end{array}$} & \multicolumn{6}{|c|}{$\begin{array}{l}\text { Site where egges were collected } \\
\text { and incubation temperature }\end{array}$} \\
\hline & \multicolumn{3}{|c|}{ Isahaya $1-2$} & \multirow{2}{*}{$\frac{\text { Isahaya } 2}{25^{\circ} \mathrm{C}}$} & \multirow{2}{*}{$\frac{\text { Isahaya } 3}{25^{\circ} \mathrm{C}}$} & \multirow{2}{*}{$\frac{\text { kuchinotsu }}{25^{\circ} \mathrm{C}}$} \\
\hline & $15^{\circ} \mathrm{C}$ & $20^{\circ} \mathrm{C}$ & $25^{\circ} \mathrm{C}^{*}$ & & & \\
\hline 0 & 0 & 0 & 0 & 0 & 0 & 0 \\
\hline 1 & 0 & 0 & 0 & 0 & 0 & 0 \\
\hline 2 & 0 & 0 & 0 & 0 & 0 & 0 \\
\hline 3 & 0 & 0 & 0 & 0 & 0 & 0 \\
\hline 4 & 0 & 0 & 0 & 0 & 0 & 0 \\
\hline 5 & 0 & 0 & 0 & 0 & 0 & 0 \\
\hline 6 & 0 & 0 & 5 & 0 & 0 & 0 \\
\hline 7 & 0 & 0 & 5 & 0 & 0 & 5 \\
\hline 8 & 0 & 0 & 19 & 3 & 0 & 6 \\
\hline 9 & 0 & 0 & 83 & 23 & 69 & 86 \\
\hline 10 & 0 & 0 & 11 & 135 & 63 & 28 \\
\hline 11 & 0 & 0 & 9 & 33 & 39 & 12 \\
\hline 12 & 0 & 0 & 13 & 19 & 0 & 7 \\
\hline 13 & 0 & 0 & 5 & 3 & 0 & 0 \\
\hline 14 & 0 & 19 & 0 & 4 & 0 & 0 \\
\hline 15 & 0 & 15 & 0 & 1 & 0 & 0 \\
\hline 16 & 0 & 32 & 0 & 0 & 0 & 0 \\
\hline 17 & 0 & 38 & 0 & 0 & 0 & 0 \\
\hline 18 & 0 & 35 & 0 & 0 & 0 & 0 \\
\hline 19 & 0 & 2 & 0 & 0 & 0 & 0 \\
\hline 20 & 0 & 13 & 0 & 0 & 0 & 0 \\
\hline 21 & 0 & 2 & 0 & 0 & 0 & 0 \\
\hline 22 & 0 & 0 & 0 & 0 & 0 & 0 \\
\hline 23 & 0 & - & - & - & - & - \\
\hline 24 & 0 & - & - & - & - & - \\
\hline 25 & 6 & - & - & - & - & - \\
\hline 26 & 5 & - & - & - & - & - \\
\hline 27 & 2 & - & - & - & - & - \\
\hline 28 & 1 & - & - & - & - & - \\
\hline 29 & 1 & - & - & - & - & - \\
\hline 30 & 0 & - & - & - & - & - \\
\hline $\begin{array}{c}\text { Total } \\
\text { nymphs }\end{array}$ & 15 & 156 & 150 & 221 & 171 & 144 \\
\hline
\end{tabular}

a) Isahaya 1 marked with an asterisk was collected on March 8 and incubated in the dark. Others were collected in late February and incubated under a 16: 8 (L: D) photoperiod. 
度を要した。このデータから定法により発育最低温度を 求めると $10^{\circ} \mathrm{C}$ 付近, 有効温量は 150 日度前後と推定され た。

ッッジグンバイ成虫の生存期間, 産卵期間は長く (NEAL and Douglass, 1988), 越冬卵は前年の10月下旬 以降に産下され休眠に入るが，卵期の肧子発育のどの段 階で休眠が起こっているか怯不明である。産下直後に休 眠に入るのではなく肧子発育の途中から休眠に入るなら 本試験で求められた卵期間の有効温量は年次により哄な ると思われ，本種のふ化時期の予察上注意を要する点で あり，休眠特性についてなお検討が必要である。

休眠明け越冬卵のふ化消長を正規分布曲線で近似する 場合，ある一定温度下に抢ける卯化の消長は次式 Yeで 表すことができる。

$$
\mathrm{Ye}(\mathrm{x})=\mathrm{n} \cdot 1 / \sqrt{2 \pi \cdot \sigma \mathrm{e}} \cdot \operatorname{EXP}\left[-(\mathrm{X}-\mu \mathrm{e})^{2} \cdot \sigma \mathrm{e}^{2}\right]
$$

ここで， $\mu \mathrm{e}$ は卵のふ化中央日（気温が発育最低温度 を越える日を起点とする)， $\sigma \mathrm{e}$ は標準偏差でありふ化 消長の単位日幅を示し， $\mathrm{n}$ は越冬卵の密度である。

従って予察に上式を利用するには，時期については発 生の幅（本実験では 3 ～）拈よび発生量の予測には定 数 $\mathrm{n}$ をあらかじめ調查しておく必要がある。

卵の休眠党醒は，一般に日長や低温接触期間に左右さ れるとされている。本調查地域におけるッッジダンバイ の越冬卯の休眠覚醒時期は本実験の 3 月 8 日採取枝の全 暗下条件下 $25^{\circ} \mathrm{C}$ 飼育でも長日条件下 $25^{\circ} \mathrm{C}$ 加温と同様なふ 化が見られることから 3 月 8 日以前と推定される。

本地域では春分の日以前の 3 月中旬までに発育最低気 温 $\left(10^{\circ} \mathrm{C}\right.$ 前後) を越える日もあるが，ふ化時期を予測す る起点は日長の影響は少ないと考えて計算してよいと思 われる。

\section{2. ッツジグンバイ幼虫各態の発育最低温度と有効}

\section{温量}

4 温度段階で飼育した幼虫の齢期間を Table 2 に示
Table 2. Mean durations of nymphal instars of Stephqnitis pyrioides reared at 4 constant temperatures ${ }^{\mathrm{a}}$.

\begin{tabular}{ccccc}
\hline $\begin{array}{c}\text { nymphal } \\
\text { instar }\end{array}$ & $15^{\circ} \mathrm{C}$ & $20^{\circ} \mathrm{C}$ & $25^{\circ} \mathrm{C}$ & $28^{\circ} \mathrm{C}$ \\
\hline 1st & $9.0 \pm 0.2$ & $4.1 \pm 0.4$ & $3.0 \pm 0.0$ & $2.5 \pm 0.3$ \\
2nd & $7.3 \pm 0.4$ & $3.0 \pm 0.0$ & $2.1 \pm 0.2$ & $1.9 \pm 0.1$ \\
$3 \mathrm{rd}$ & $7.2 \pm 0.7$ & $3.7 \pm 0.3$ & $2.1 \pm 0.2$ & $2.1 \pm 0.3$ \\
4 th & $7.0 \pm 1.0$ & $4.3 \pm 0.5$ & $2.6 \pm 0.3$ & $2.4 \pm 0.7$ \\
5 th & $10.5 \pm 0.4$ & $6.9 \pm 0.5$ & $3.9 \pm 0.5$ & $3.2 \pm 0.5$ \\
\hline Total & $41.0 \pm 2.7$ & $21.0 \pm 1.7$ & $13.6 \pm 1.4$ & $12.1 \pm 2.0$ \\
\hline
\end{tabular}

a) Figures indicate mean durations in day and standard deviations.

した。15 28 ${ }^{\circ} \mathrm{C}$ 間での 1 齢奻虫期間は9.0〜2.5日，2 齢 幼虫期間は7.3 1.9日，3龄幼虫期間は，7.2 2.1日， 4 齢幼虫期間は7.0 2.4日，5秢幼虫期間は $10.5 \sim 3.2$ 日であった。全幼虫期間は， $15^{\circ} \mathrm{Cで} 41.0$ 日， $20^{\circ} \mathrm{C} て ゙ 21.0$ 日， $25^{\circ} \mathrm{C} て ゙ 13.6 日 ， 28$ 度では12.1日であった。また，各 齢の発育所要日数は各飼育温度とも，1 齢と 5 齢幼虫が $2 \sim 4$ 秢幼虫に比べてやや長い傾向にあった。

個体飼育の結果から各齢期の発育速度と温度との関保 をみるといずれの齢期においても高い相関関係が認めら れた (Table 3)。この回帰直線式から求めた $1 － 5$ 齢幼 虫の発有最低温度はそれぞれ $9.5 ， 9.5 ， 9.9 ， 8.8 ， 10.3$ の各温度 $\left({ }^{\circ} \mathrm{C}\right)$ であった。また，全幼虫期の発育最低温 度は9. $6^{\circ} \mathrm{C}$, 本虫のふ化後成虫までの有効温量は218日度 と推定された。

\section{3. 越冬状況と発生消長}

1992年の発生状況

1992年 3 月 1 日にバット払い落し法, 粘着板払い落し 法や見取り法により成虫調查を行ったが越冬成虫は確認 できなかった。また同日に20枝を摘採し $25^{\circ} \mathrm{C}$ ，長日下で 保持した試験でも幼虫のふ化は確認できなかった。しか し，定植間もない 3 年生のッッジである諫早 $1-1$ の以 外の諫早 $1-2$, 諫早 2 では後述のと扔り，4月に幼虫 のふ化を認め,これらの地点では卵で越冬していたと考

Table 3. Developmental zeros and total effective temperatures of nymphal instars of Siephanitis pyrioides ${ }^{\text {a) }}$

\begin{tabular}{llcrcr}
\hline \hline $\begin{array}{c}\text { Nymphal } \\
\text { instar }\end{array}$ & Regression equation & $\mathrm{R}$ & $\begin{array}{c}\text { Developmental } \\
\text { zero } \\
\left({ }^{\circ} \mathrm{C}\right)\end{array}$ & $\begin{array}{c}\text { Total } \\
\text { effective } \\
\text { day-degrs }\end{array}$ \\
\hline 1st & $\mathrm{Y}=-0.20707+0.02178 \mathrm{X}$ & $\mathrm{R}=0.99643$ & 9.51 & 48.7 \\
2nd & $\mathrm{Y}=-0.27769+0.02933 \mathrm{X}$ & $\mathrm{R}=0.97102$ & 9.46 & 37.5 \\
3rd & $\mathrm{Y}=-0.28211+0.02830 \mathrm{X}$ & $\mathrm{R}=0.97579$ & 9.97 & 36.0 \\
4th & $\mathrm{Y}=-0.19717+0.02233 \mathrm{X}$ & $\mathrm{R}=0.98998$ & 8.83 & 52.2 \\
5th & $\mathrm{Y}=-0.17660+0.01722 \mathrm{X}$ & $\mathrm{R}=0.98716$ & 10.25 & 57.6 \\
Whole & $\mathrm{Y}=-0.04408+0.00459 \mathrm{X}$ & $\mathrm{R}=0.99724$ & 9.59 & 217.9 \\
\hline
\end{tabular}

a) $\mathrm{R}, \mathrm{X}$ and $\mathrm{Y}$ indicate the correlation coefficient, reared temperature and developmental rate of each instar, respectively. 

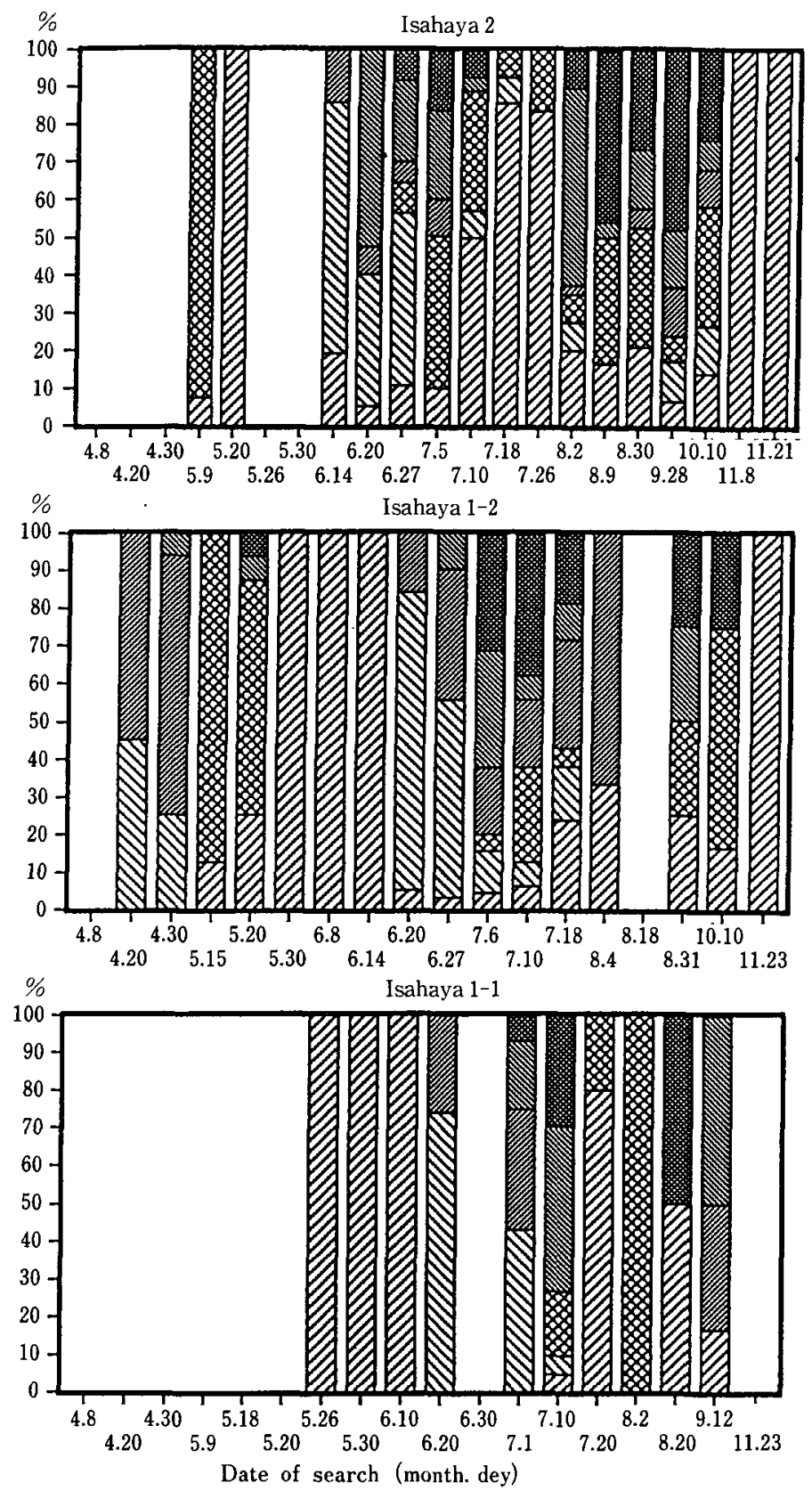

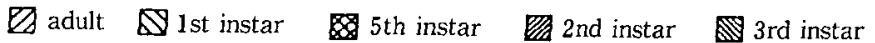

Fig. 1. Seasonal occurence of Stephanitis pyrioides at 3 sites in Isahaya city, Nagasaki (1992). Shown in percentage of adult or nymphal instars to total individuals observed.

\section{えられる。}

1992年の発生量は各地点とも少なく調査間隔も不定期 だったので各幼虫秢期の虫数そのものを示さず，各態の 比率で示した (Fig. 1)。越冬世代の 1 跲幼虫（越冬卵か
らふ化した幼虫）の発生は諫早 1 -1では見られず, 諫 早 1-2では 4月20日頃，諫早 2 では 4 月上旬にみられ た。 
越冬世代の成虫は諫早 $1-2$ と諫早 2 では 5 月15日頃 にみられた。諫早 1 - 1 では卵または成虫の越冬はなか ったと思わ扎たが，近隣の発生圃から飛来したと考えら れる成虫が5月26日に見られた。

第 1 世代の幼虫のふ化は諫早 $1-1$, 諫早 $1-2$, 諫 早 203 調查地点ともに6月20日に認め，5 栯幼虫は 7 月 5 - 10日頃に，成虫は 7 月 20 日過ぎに出現した。第 2 世代幼虫のふ化時期は各地点とも判然としなかったが 5 齢幼虫は 8 月下旬から認められるようになり，2 世代成 虫は 8 月中下旬に出現した。第 3 世代幼虫もふ化時期は 判然としなかったが5 歯幼虫は10月10日頃にみられた。 1993年の発生状況

Table 4 に1993年の調查結果を示した。2月1日のバ ットまたは粘着板払い落し法や見取り法による調査では 越冬成虫は確認できなかった。しかし2月～3月に20枝

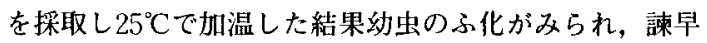
$1-1$, 諫早 $1-2$, 諫早 2 のいずれにおいても卵越冬 を確認した。

1993年の越冬世代の 1 齢幼虫（越冬卵からのふ化幼
虫) は諫早 $1-1$, 諫早 $1-2$, 諌早 203 地点ともに 4 月17日に発生を認めた。幼虫はその後藏期を重ね諫早 $1-1$, 諫早 $1-2$, 諫早 2 では 5 月20日前にほぼ5 龄 に達した。越冬世代成虫は諫早 1 -1において 5 月28日 に確認した。

第 1 世代の 1 龄幼虫の発生は諫早 $1-1$ では 6 月23日， 諫早 1 - 2 では 6 月15日, 諫早 2 では 6 月13日であった。 同世代の 5 齢幼虫は調查各地点とも 7 月24日に認めた。 また第 1 世代成虫は越冬世代成虫出現から 2 力月後の 7 月10〜24日頃に出現した。

第 2 世代 1 跲幼虫の出現時期は調査地点間でやや異な るが7月下旬一 8 月 2 日に, 同 5 齢は 9 月 2 半旬〜 4 半 旬頃と推定された。第 2 世代成虫は 9 月上旬に観察され た。第 3 世代の 1 齢幼虫は 9 月中旬, 同 5 齡幼虫は 9 月 下旬にみら机た。第 3 世代と思われる成虫は 10 月中旬以 降に認めた。

以上のように本種には 5 月中旬以降に出現した越冬世 代を含めて年 4 回の成虫期が認められた。

1993年は台風の襲来による発生の乱れが 8 月中旬以降

Table 4. Seasonal prevalence of Stephanitis pyrioides at 3 sites in Isahaya city, Nagasaki $(1993)^{\text {a) }}$

\begin{tabular}{|c|c|c|c|c|c|c|c|c|c|c|c|c|}
\hline \multirow{3}{*}{$\begin{array}{c}\text { Date of } \\
\text { search. } \\
\text { (Month/ } \\
\text { day) }\end{array}$} & \multicolumn{4}{|c|}{ Isahaya 1-1 } & \multicolumn{4}{|c|}{ Isahaya 1-2 } & \multicolumn{4}{|c|}{ Isahaya 2} \\
\hline & \multirow{2}{*}{$\begin{array}{l}\text { No. } \\
\text { of } \\
\text { adult }\end{array}$} & \multicolumn{3}{|c|}{ No. of nymph } & \multirow{2}{*}{$\begin{array}{l}\text { No. } \\
\text { of } \\
\text { adult }\end{array}$} & \multicolumn{3}{|c|}{ No, of nymph } & \multirow{2}{*}{$\begin{array}{c}\text { No. } \\
\text { of } \\
\text { adult }\end{array}$} & \multicolumn{3}{|c|}{ No. of nymph } \\
\hline & & $\begin{array}{l}\text { 1st } \\
\text { instar }\end{array}$ & $\begin{array}{l}\text { 2nd-4th } \\
\text { instar }\end{array}$ & $\begin{array}{l}5 \text { th } \\
\text { instar }\end{array}$ & & $\begin{array}{l}\text { 1st } \\
\text { instar }\end{array}$ & $\begin{array}{c}\text { 2nd-4th } \\
\text { instar }\end{array}$ & $\begin{array}{l}5 \text { th } \\
\text { instar }\end{array}$ & & $\begin{array}{l}\text { 1st } \\
\text { instar }\end{array}$ & $\begin{array}{l}\text { 2nd-4th } \\
\text { instar }\end{array}$ & $\begin{array}{l}5 \text { th } \\
\text { instar }\end{array}$ \\
\hline $4 / 15$ & - & - & - & - & 0 & 0 & 0 & 0 & - & - & - & - \\
\hline 17 & 0 & 0.3 & 0 & 0 & 0 & 6 & 0 & 0 & 0 & 29.3 & 0 & 0 \\
\hline 25 & - & - & - & - & 0 & 20.2 & 5.6 & 0 & 0 & 3.8 & 38.4 & 0 \\
\hline $5 / 1$ & 0 & 0 & 0.6 & 0 & 0 & 4.2 & 13.4 & 0 & 0 & 0 & 34.6 & 2.5 \\
\hline 8 & - & - & - & - & - & - & - & - & 0.3 & 0.3 & 15.0 & 24.0 \\
\hline 11 & 0 & 0 & 1.0 & 0.1 & 0 & 0.5 & 30.7 & 14.5 & - & - & - & - \\
\hline 15 & - & - & - & - & - & - & - & - & 19.8 & 0 & 29.9 & 29.8 \\
\hline 17 & - & - & - & - & 0 & 0 & 4.4 & 16.4 & 106.5 & 0 & 1.0 & 1.0 \\
\hline 19 & 0 & 0 & 0.1 & 0.8 & - & - & - & - & - & - & - & - \\
\hline 28 & 0.5 & 0 & 0 & 0 & - & - & - & - & - & - & - & - \\
\hline $6 / 15$ & - & - & - & - & 0.8 & 0 & 0 & 0 & 6.1 & 6.4 & 0.7 & 0 \\
\hline 19 & - & - & - & - & 1.2 & 18.5 & 0 & 0 & 4.7 & 32.7 & 3.3 & 0 \\
\hline 23 & 0.5 & 2.6 & 0.4 & 0 & 0.2 & 6.4 & 1.5 & 0 & 1.0 & 9.3 & 1.5 & 0 \\
\hline $7 / 3$ & 0.3 & 0.2 & 3.8 & 0.2 & 0.2 & 8.0 & 6.0 & 0 & 0.8 & 30.7 & 19.5 & 1.5 \\
\hline 9 & 0.1 & 0.5 & 2.4 & 1.4 & 0.3 & 1.2 & 5.8 & 0.2 & 0.5 & 3.0 & 13.8 & 1.5 \\
\hline 15 & 1.1 & 0.1 & 4.1 & 1.0 & 0.1 & 0.8 & 5.1 & 0.5 & 1.8 & 0 & 0.6 & 0.4 \\
\hline 24 & 3.1 & 0 & 0.6 & 1.8 & 0.2 & 0 & 0.6 & 3.2 & 1.8 & 0 & 0 & 0.1 \\
\hline $8 / 2$ & 1.0 & 0.5 & 0.5 & 0.1 & 0.1 & 0 & 1.7 & 0 & 1.1 & 3.4 & 0 & 0 \\
\hline 9 & 2.0 & 0.8 & 4.9 & 0.1 & 0 & 0 & 0 & 0 & 1.5 & 2.5 & 5.5 & 0.3 \\
\hline 22 & 1.0 & 0.2 & 2.4 & 0.4 & 0.1 & 0 & 0.6 & 0 & 0.7 & 2.1 & 1.2 & 0.2 \\
\hline 28 & 1.1 & 0.5 & 2.8 & 1.2 & 0.1 & 0 & 0.4 & 0.4 & 1.3 & 1.2 & 7.5 & 1.2 \\
\hline $9 / 5$ & 0.6 & 0 & 1.5 & 2.2 & 0.1 & 0 & 5.4 & 2.0 & 0.6 & 1.8 & 0.2 & 0 \\
\hline 12 & 3.0 & 0.7 & 9.2 & 2.3 & 0.3 & 0 & 3.5 & 1.6 & 0 & 0 & 0.7 & 0.2 \\
\hline 19 & 1.0 & 0 & 3.5 & 2.3 & 0 & 0 & 1.5 & 1.0 & 0.2 & 1.4 & 5.0 & 0.4 \\
\hline 28 & 1.4 & 0 & 3.4 & 4.9 & 0.5 & 0.5 & 1.3 & 1.8 & 1.1 & 0 & 11.1 & 0.6 \\
\hline - $10 / 11$ & 4.2 & 0.1 & 0.1 & 1.5 & 1.3 & 0 & 0 & 0.7 & 3.3 & 0 & 0 & 0.7 \\
\hline 24 & 3.3 & 0 & 0.2 & 1.2 & 1.6 & 0 & 0.2 & 2.0 & 6.4 & 0 & 0 & 0 \\
\hline 30 & 2.8 & 0 & 0 & 0.8 & 2.7 & 0 & 0 & 1.5 & 2.8 & 0 & 0 & 0 \\
\hline $11 / 13$ & 5.4 & 0 & 0 & 0.1 & 4.0 & 0 & 0 & 0 & 10.5 & 0 & 0 & 0 \\
\hline $12 / 13$ & 2.3 & 0 & 0 & 0 & 2.2 & 0 & 0 & 0 & 2.2 & 0 & 0 & 0 \\
\hline
\end{tabular}

a) Figures indicate the numbers of adults or nymphs observed on 5 branches of azalea. 


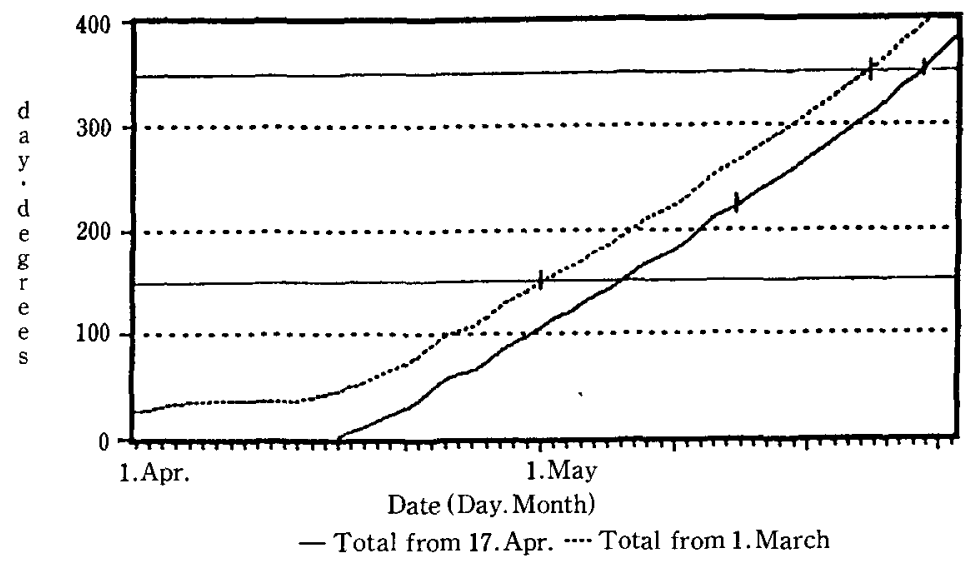

Fig. 2. Total effective temperatures of the overwintered generation of Stephanitis pyrioides estimated in Isahaya city, Nagasaki in 1993.

9 月中旬頃まで見られ，秋の発生は地点によつて明睹で なかった。発生量洁1992年よりも多く, 越冬世代成虫の 発生時期は早かった。

4. 有効皘算温量を用いたツツジグンバイの予測発生 時期と現況の比較

窒内飼有によって得られたツツジグンバイの各態の発 有最低温度から本種の卵, 幼虫各態の全体の平均として

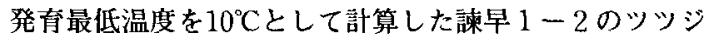
に怙けるッッジグンバイの3月1日〜 5 月31日までの有 効積算温量を Fig. 2 に示した。

越冬卵及び全幼虫期間の有効温量をそれぞれ150日度， 218日度（合計では368日度）とし，3月1日を起点とし た有効積算温量から予測される越冬卵のふ化時期は 4 月 6 半旬 -5 月 1 半旬, 幼虫期完了の時期即与越冬世代成 虫出現時期は 5 月 4 - 5 半旬なる。

これを1993年の現況と比較すると，ふ化時期について は予測したふ化時期は現況の 4 月17日より15日程度羊い 結果であった。

この原因としては越冬卵の休眠開始時期の発育程度や 卵の産下部位がッッジの葉寒の葉脈内であり,この部位 の温度と気温の差異が考えられ，越冬世代卵のふ化時期 を正確に予測するには，これらの点についてさらに検討 が必要である。

幼虫期の完了時期（越冬世代成虫出現時期）について は 3 月 1 日を起点とした有効積算温量368日度にあたる 時期 (Fig. 2 の点線) 怯現況の越冬世代成虫の出現時期
とほぼ同時期であった。また諫早 1-1で越冬世代の幼 虫のふ化を確認した 4 月17日を起点とした有効積算温量 218日度にあたる時期は 5 月15日頃（Fig. 2 の実線）で あった。したがって1 齢幼虫出現時期を確認した後の龄 期の進行や第 1 世代成虫発生時期の予測には本試験結果 を利用できると思われる。

第 1 世代以降の予測は，本種の成虫の産卵前期間を NEAL and DOUGLASS (1988) による夏季の気温 $26^{\circ} \mathrm{C}$ 前後 下の7日，また卵期間を13日（合計20日）として，各世 代の 1 秢幼虫のふ化時期を設定し，龄期の進行は本実駼 の発育最低温度と有効積算温量および $20^{\circ} \mathrm{C}$ 下の幼虫期間 21 日，25ㄷ14日索考として発生時期を予測すると， 各世代の成虫の発生時期は 7 月中下旬，8月下旬，9月 下旬となり野外に打けるッッジグンバイの発生実態とほ ぼ類似した結果が得られた。

しかし, 本種の発生予察を長期的に, より正確に予測 するには，夏季の卵の発育生態や産卵前期間等の基礎的 な調查を抗こなう必要がある。また発生量については, 当年の発生源である越冬卵の密度やふ化幼虫の密度変化 に与える気象，捕食性天敵等の要因により変動すると考 えられ，これらの点についての調査検討も必要である。

\section{引用 文 献}

1) NeAL, J. W. JR. and Douglass, L. W. (1988) Environ. Entomo. 17: 817-831. 2) 中須賀孝正 (1993) 九病虫研会報 $39: 164$. 3) TAKEYA, C. (1963) Mushi. 37(4):27-52.

(1994年 4 月30日 受領) 